\title{
Anthropocentrism in the Select American Dystopic Fictions: The Water Knife by Paolo Bacigalupi and Claire Vaye Watkins' Gold Fame Citrus
}

\author{
Rajesh K. \\ Vellore Institute of Technology, Chennai \\ Rajasekaran V. \\ Vellore Institute of Technology, Chennai
}

\begin{abstract}
A conductive environment is the most crucial thing for any living being to lead life happily in the world. The environment includes both biotic and abiotic components. At present, people are facing more problems due to environmental issues. This research paper aims to see anthropocentrism through the interaction between humans and the environment in the select American dystopic fictions The Water Knife by Paolo Bacigalupi and Gold Fame Citrus by Claire Vaye Watkins. These novels' major themes deal with climate change, water shortage, drought, and other ecological crises. In this research, a qualitative approach has been taken up as a method. The result of the study reveals that humans have more responsibilities to protect water bodies and the environment. People need to follow ethics effectively and not be involved in anthropocentric activities to come out of water shortages. The study reminds us that nature is more powerful than man.
\end{abstract}

Keywords: ethics, environmental ethics, anthropocentrism, interaction between humans and environment, The Water Knife, Gold Fame Citrus

\section{INTRODUCTION}

Any living being can co-exist in this world following the natural laws and being sensible towards the environment. Humans are responsible for protecting the surroundings (environment) to maintain the balance between humans and the environment. If it is imbalanced, the world needs to face an environmental crisis like water problems, climate change, pollution, deforestation, biodiversity, etc. Environmental issues are taking place due to technological advancements and human unethical behaviours towards the environment. There is a fundamental view in the philosophy that man has only intrinsic value and other beings do not have. This kind of human perspective on nature caused the environmental crisis. Therefore, man needs to change his lifestyle to protect the natural resources (water, air, soil) and stop killing the animals, destroying forests, polluting water, air, and land to live a better life. 


\section{LITERATURE REVIEW}

Kuper in his article "Thoreau, Leopold, \& Carson: Challenging Capitalist Conceptions of the Natural Environment", says that Henry David Thoreau, Aldo Leopold, and Rachel Carson have critically analyzed anthropocentrism through their works Walden (1854), A Sand County Almanac (1949) and Silent Spring (1962) in the different periods. Besides, they point out that nature has its intrinsic value (Kuper).

The article titled "Aristotle: Phusis, Praxis, and the Good": Orphan explains that Aristotle mentioned nonhumans only in Politics and not elsewhere. Also, he rejects the ideology of nature (Orhan).

Kopnina, Washington, Taylor \& Piccolo in their article "Anthropocentrism: More than Just a Misunderstood Problem", say that Hayward has strongly supported anthropocentrism. It is advantageous to discuss human chauvinism towards nonhuman beings and their responsibilities on nature (Kopnina, Washington, Taylor \& Piccolo).

In the article titled "Addressing Anthropocentrism in Nonhuman Ethics: Evolution, Morality, and Nonhuman Moral Beings", Woodhall explains that the modern theories of Peter Singer's Utilitarianism and Tom Regan's Deontological rights-based theory are not addressed about biotic community accurately (Woodhall).

In the article titled "Using anthropocentrism to the benefit of other species", Wilson discusses Chapman and Huffman dispute and views that there is no need to recognize humans as the centre of the earth and distinctive from the biotic community (Wilson \&Vanessa).

\section{METHODOLOGY}

The present research attempts to focus on anthropocentrism as seen through the interaction between humans and the environment in the select American dystopic fictions. The chosen fictions are Water Knife by Paolo Bacigalupi and Claire Vaye Watkins' Gold Fame Citrus. It also tries to do a parallel analysis of other sources and a critical study of human behaviour in the context of anthropocentrism.

\section{MAIN THEORIES FOR THIS STUDY}

'Ethics', the term is originated from the Greek word Ethos, which means the customs, traditions, and habits of people. 'Morality' is derived from the Latin mos, moris which denotes fundamentally the same meaning, and it has been introduced by Cicero as corresponding meaning to the Greek ethos (Singh, D). Besides, Taback and Ramanan have defined that "Ethics is the difference between what a person has the right to do and the right thing to do!" (Taback and Ramanan. p.11). Environmental Ethics is one of the divisions of Environmental Philosophy. It is an ethical correlation between man and the natural environment (Buzzle). Environmental ethics is mainly divided into two types anthropocentrism and nonanthropocentrism. It primarily focused on both biotic and abiotic components in the environment and the human impact on the surroundings. Wilson defines that "The anthropocentric perception is widespread and is considered to be responsible for severe environmental crisis ranging from global warming, ozone depletion and water scarcity to the loss of biological diversity" (Wilson).

\section{ANTHROPOCENTRISM AS SEEN THROUGH THE INTERACTION BETWEEN HUMANS AND THE ENVIRONMENT}

\section{The Water Knife}

The Water Knife is set in California's near future when the southern states Las Vegas and Phoenix have competed for water supply during drought. Catherine Case and Angel live in Las Vegas, and they attempt to get a fair share of water to Nevada from the Colorado River. Angel lives a luxurious life and commits violence on behalf of Case. Besides, Las Vegas authorities direct Maria, Sarah and Toomie to gain water rights from Phoenix people. In the other side, Maria and Lucy live in Phoenix. Catherine case sends Angel to inspect water sources in Phoenix. Lucy, a journalist, discovers her friend Jamie murdered when he 
involves in selling water rights. Later, Lucy rescued her sister Anna from Catherine case. Angel recognizes that Catherine has misunderstood Jamie that she had stolen water rights. Later, Angel realizes that water rights documents are inside Maria's new book from Ratan's apartment. In the end, Lucy and Angel found Maria near Carver city where she tries to cross the boundary to escape from them. Lucy reads the water rights documents that help to save Phoenix, and she decides to return to Arizona. But Maria has shot Lucy allowing Angel to regain her possession of the water rights.

\section{Corporate Greed and Climate Change}

Angel is the protagonist of the novel The Water Knife, and the main story revolves around her actions. She works as a secret agent in the state of Nevada. Angel's boss Catherine orders her to inspect water resources around the Colorado River. To obey her boss, she flies to the south and walks on the Colorado River Bridge to check the water logs, where she sees militants illegally carrying the water through Lorries. In the meantime, Gover, an officer is arrested for emptying water hoists illegally to the construction work and maintaining greenery gardens. In chapter seven, Angel (who is an assistant and working as a spy to his boss Catherine Case) feels happy that her native corporate people have stolen water bodies for various purposes and she says

"Thanks to the centrifugal pump, places like Nebraska, Kansas, Oklahoma, and Texas had thrown on the garments of fertility for a century, pretending to greenery and growth as they mined glacial water from ten-thousand-year-old aquifers. They'd played dress-up-in-green and pretended it could last forever. (Bacigalupi, pg. 80).

The above lines describe that even Phoenix people in the city do not have enough water for their daily chores. Still, corporate people Catherine Case (Boss) and Angel Velasquez (spy) are grabbing the water illegally from Nebraska, Kansas, Oklahoma, and Texas rivers and trying to manage archaeological greenery developments in Las Vegas. These kinds of temporary greenery developments in Las Vegas have affected Phoenix people's livelihood and created violence. Apart from this, a massive water shortage problem could happen in the whole city. This kind of immoral action and anthropocentric attitude of corporate people Angel and Catherine and their greed could cause significant difficulties and environmental crises for ordinary people of the city.

\section{Water Shortage and Drought}

There is a conversation between an older man Toomie and Maria, a teen refugee in Chapter eight. Toomie explains Chinese archaeology and says, "God damn, and I thought building houses was bad" (Bacigalupi, p.91). Maria replies to Toomie that "Everything's bad until you find something worse" (Bacigalupi, p.91). Based on this conversation, it can be understood that building houses is hazardous because it needs an excess of water. Once building work is finished, many people could occupy the new buildings and dump with overpopulation. Again, it multiplies various problems like excess water consumption in the apartments and increases wastewater and garbage. This kind of anthropocentric attitude of humans creates a significant water imbalance between humans and other living beings in the environment. Finally, it leads to drought in the future.

The Colorado city is full of dust, and in chapter nine, Zoners have complained that 'If we weren't wasting so much water on farming, we'd all be fine. Cut the rest of the farms off. I don't care how senior their rights are. They're the ones wasting it" (Bacigalupi, p.100). Zoners have indicated that farming could dry the dams and formed dust storms in the city due to more water usage for agriculture. If the excess water is not used for agriculture, it would be sufficient to hold it in dams for long time usage. But, Angel says to Julio that "About what that last idiot said. If you cut off farms, you got dust storms. Simple as that. Where the hell does he think all this dust is coming from - " (Bacigalupi, p.100). In the view of Angel, Zoners only complained about water usage for farming. They never complained about other dangerous usages of water like constructing new buildings, temporary greenery development projects, etc. Moreover, Angel and the Zoners are fighting among themselves and forgot their ethical responsibilities to preserve water bodies and 
illegally stole water for various purposes. This kind of anthropocentric behaviour of the people on water resources and their irresponsibility could be the fundamental reason for future drought in California.

In chapter sixteen, Angel and Lucy have protested against the local government, and Angel says that "Desperate people did desperate things, became avatars of unexpected tragedy" (Bacigalupi, p.157). At this point, Angel directly points out the irresponsibility of people and their anthropocentric behaviour on the water resources. Humans are fighting among themselves with greed, and they are always thinking about temporary happiness in the present situation and forget about the future's permanent problems. This anthropocentric attitude towards the environment leads to a significant water shortage, and later it becomes a big drought. Moreover, the water crisis's future conditions remind us that water is more valuable than anything. Humans have a huge responsibility to save water bodies for the future.

Two distinctive economic classes of people are living in the city of California. The first group, California people, uses excess water more than their need, and the second group of people are Phoenix, who are fighting to get water to live. In chapter twenty-seven, Jamie and Lucy talk about the water rights; here, Lucy says "Which means Phoenix and Arizona trump California. Cali's got senior rights on four million acre-feet of water. Still, if that gets taken away from them - they've got the Imperial Valley and fifty million people depending on that water"(Bacigalupi, p.233). The second group of Phoenix people, those who fought to get water to live could not reach the upper-class economic people, because California people owned the water rights and the remaining Phoenix people toiled in overheat without water. Above quote shows the interaction between humans and the environment and how people are fighting among themselves without ethics. This kind of anthropocentric behaviour of humans is the leading cause of the environmental crisis like water shortage and extreme drought in California.

The man does not treat nature with generosity and does not follow ethics. Man has developed anthropocentric behaviour on nature and has started quarrelling among his political and social power groups. Humans use their political and social influence on the environment, sell water illegally to corporate companies, and involve in unrecognized building constructions, destroy forests for illegal real estate business, and kill wild animals for various unethical purposes. Therefore, human's unethical behaviour leads to various environmental crises.

In addition to this, Geoscience Professor Lain Stewart remind us and mention the futuristic view on water crises of the entire world that

"According to an article by Iain Stewart, a broadcaster for BBC and a professor of Geoscience Communication at the University of Plymouth, in as little as 15 years, half the world's population could be living in areas with high water stress. Areas like this are places that have a hard time finding fresh water, whether that is above ground or below, to drink and live with. This is unbelievable at first, but it's also crazy to think that $97 \%$ of the world's water is salt water. The amount of fresh water we have is limited, and we must use it sparingly" (Zach Bigley).

\section{Gold Fame Citrus}

Claire Vaye Watkins is an American dystopic fiction writer. The novel Gold Fame Citrus concerns an imaginary near-future of California damaged by drought. The novel is divided into three parts Book one, Book two and Book three. Book one is a description of Luz and Ray, and later Ray explains to Luz about California's past life. Once the state was famous for its gold rushes, film industry and fruit orchids (justification of the title (Gold Fame Citrus). Later the state government sent people to labour camps, where they called 'Mojave' without having enough money to live. The book two, the author has kept the characters in the foreground and provided an omniscient narration view of the Amargosa dune sea. She gives more importance to climate changes and environmental degradation rather than people. Dallas, a woman, tells the history of Mojaves to Estrella (Ig). Book three shifts to Ray's experience when Luz left. Watkins maintained a relentless focus on the people's stuff and focused on the narrative about Luz, Ray and Ig's human relationships. 


\section{Nature}

Luzz Dunn is the protagonist and a former model. The Bureau of conservation has symbolically adopted her. Ray is Luzz's boyfriend. When Ray talks first-time to Luzz, he explains California people's past life and how human generations and wanderers have made California's current situation. He says that "Your people came here looking for something better. Gold, fame, citrus. Mirage. They were feckless, yeah? Schemers. That's why no one wants them now. Mojave" (Watkins, P.23). These lines precisely justify Gold Fame Citrus's book title as the title describes an interaction between humans and the environment. Earlier the state of California named for its gold rushes, film industry, and fruit orchard. The title 'Gold' represents California people's wealth, 'fame' represents the film industry, and their luxurious life, and 'Citrus' represents the fruit orchards. Whereas Mojavs (refugees), the immigrant community came to California to live a better life. Still, now their condition is deplorable without money.

The population (Mojavs) is very high, and they do not have enough money to live. Moreover, California's government has evacuated state people to labour camps because the state is filled with full of the dust bowl and the labour camps. Indiana has refused to allow them that "MOJAVS NOT WELCOME. NO WORK FOR MOJAVS. MOJAVS KEEP OUT" (Watkins, P.23). It indicates that California people are currently living their busy life always paying attention to rich and luxurious life and least bothered about saving water resources and nature. This kind of lack of interest in protecting water resources may lead to California's future drought, and also people would face more difficulties to live their everyday life.

In book two of the novel, the author, Watkins describes the dark side of the celebrity life of California people and the psychic impact of the place Armargosa that

"Who had drained first Owens Lake then Mono Lake, Mammoth Lake, Lake Havasu, and so on, leaving behind wide white smears of dust? Who had diverted the coast's rainwater and sapped the Great Basin of its groundwater? Who had tunnelled beneath Lake Mead, installed a gaping outlet at its bottommost point, and drained it like a sink? Who had sucked up the Ogallala Aquifer, the Rio Grande aquifer, the snowpack of the Sierras and the Cascades? If this was God, he went by new names: Los Angeles City Council, Los Angeles Department of Water and Power, City of San Diego, City of Phoenix, Arizona Water, and Power, New Mexico Water Commission, Las Vegas Housing and Water Authority, Bureau of Land Management, United States Department of the Interior" (Watkins, P.120).

In the above lines, author Watkins has directly blamed unethical interaction between humans and the environment. In California, people have drained the lakes using different political and power structures in other names like water commission and water authority. California's most significant drought causes this kind of selfish behaviour of humans towards the water bodies (lakes). In addition to this, Watkins personified nature as alive and more dangerous than the human. It indicates that nature reflects according to human behaviour. If human create problems to nature, similarly nature may react.

\section{CONCLUSION}

In light of the evidence, it is crystal clear that both American dystopic fictions have set in the near future with the common problem of water scarcity and drought. It throws light on the current water problems scenario mentioned in America's dystopic fiction locations and applies to the present-day world. In the novel, water scarcity is happening in the future, but it applies to the world's current scenario. This kind of water problem has happened because of people's immoral actions and their anthropocentric attitude (greedy, selfish) towards the environment like lavish water usage, cutting down the trees for various purposes, contaminated water, and air, plastic wastages and ejection of poison gases. These kinds of unethical interactions between humans and the environment lead to multiple natural hazards like floods, earthquakes, water scarcity, etc.

Moreover, the author, Watkins, has personified nature as alive and more powerful than a human. If people respect and protect wildlife, nature also protects the human. If people are greedy and selfish towards 
nature, nature also gives more problems to human. To prevent these dilemmas, people need to behave responsibly and give up anthropocentric attitude towards the environment to protect natural resources.

\section{REFERENCES}

Bacigalupi, P. (2015). The Water Knife. New York: Alfred A. Knopf, 2015.

Bigley, Z. (2015, January 15). The Water is Going, Going... Gone? ENG 104: Climate Change Fiction. Retrieved March 16, 2020, from blogs.uoregon.edu/eng104/2015/01/15/the-water-is-going-goinggone/\#more-115

Kopnina, H., Washington, H., Taylor, B., \& Piccolo, J.J. (2018). Anthropocentrism: More than Just a Misunderstood Problem. Journal of Agricultural and Environmental Ethics, 31(1), 109-127. doi:10.1007/s10806-018-9711-1

Kuper, S. (2014). Thoreau, Leopold, \& Carson: Challenging Capitalist Conceptions of the Natural Environment. Consilience: The Journal of Sustainable Development, 13(1), 267-284. Retrieved from https://consiliencejournal.org/wp-content/uploads/sites/25/2016/09/393-1016-4-PB.pdf

Oak, M. (2011). What is Environmental Ethics? Buzzle. Retrieved February 10, 2012, from http://www.buzzle.com/articles/what-is-environmental-ethics.html

Orhan, Ö. (2015). Aristotle: Phusis, Praxis, and the Good. Engaging Nature, pp. 45-64. doi:10.7551/mitpress/9780262028059.003.0003

Singh, D. (n.d.). Ethics Moralitybwnewfont. Academia.edu. Retrieved October 1, 2019, from www.academia.edu/8940638/Ethics_moralitybwnewfont

Taback, H., \& Ramanan, R. (2014). Environmental Ethics and Sustainability: A Casebook for Environmental Professionals. CRC Press.

Watkins, C.V. (2017). Gold Fame Citrus. Riverrun.

Wilson, E.O. (2003). The Future of Life. Vintage.

Wilson, V. (2018). Using Anthropocentrism to the Benefit of Other Species. Animal Sentience, 3(23). doi:10.51291/2377-7478.1381

Woodhall, A.C. (2017). Addressing Anthropocentrism in Nonhuman Ethics: Evolution, Morality, and Nonhuman Moral Beings. University of Birmingham. Retrieved from http://etheses.bham.ac.uk/id/eprint/7186 